\title{
Plant knowledge richness in the Sundanese upland village: A case study in Sindangsari, West Java, Indonesia
}

\author{
RINI SOEMARWOTO ${ }^{1, \boldsymbol{v}}$, JOHAN ISKANDAR $\mathbf{R}^{2,3, v v}$ \\ ${ }^{1}$ Department of Anthropology, Faculty of Social and Political Sciences, Universitas Padjadjaran. J1. Raya Bandung-Sumedang Km. 21, Jatinangor, \\ Sumedang 45363, West Java, Indonesia. Tel.: +62-22-7798418, `email: r.s.soemarwoto@unpad.ac.id \\ ${ }^{2}$ Department of Biology, Faculty of Mathematics and Natural Sciences, Universitas Padjadjaran. J1. Raya Bandung-Sumedang Km 21, Jatinangor, \\ Sumedang 45363, West Java, Indonesia. Tel./fax.: +62-22-7796412, ${ }^{\text {v }}$ email: johan.iskandar@unpad.ac.id \\ ${ }^{3}$ CESS-CENTER for Environment and Sustainability Science, Universitas Padjadjaran. Jl. Raya Bandung-Sumedang Km 21, Jatinangor, Sumedang \\ 45363, West Java, Indonesia
}

Manuscript received: 30 May 2021. Revision accepted: 16 August 2021.

\begin{abstract}
Soemarwoto R, Iskandar J. 2021. Plant knowledge richness in the Sundanese upland village: A case study in Sindangsari, West Java, Indonesia. Biodiversitas 22: 3722-3735. According to ecological history, Sundanese people of West Java, Indonesia, have highly rich knowledge of plants. However, due to population increase, rapid development of market economy, and rapid change of rural ecosystem, the local plants knowledge has tended to decrease rapidly. This research's objective is to elucidate the plant knowledge richness of the Sundanese. The study was undertaken in the upland village of Sindangsari, West Java, using mixed-method with ethnobotanical approach, from July to August 2017, and March 2018. The study found 204 landraces which consisted of 181 species, representing 161 genera, and 70 families. The use of plants could be classified into food, spices, medicine, construction, ornament, cosmetic, commercial plants, fodder, industry, food color, erosion control, and social function. The highest secondary citations, that is plants for food and medicine, were known by less than $50 \%$ of respondents; other plants were hardly known, recognized only by $0.1 \%$ to $0.5 \%$ of respondents. The results showed little practical knowledge among the younger generation. The intensive mobility of young population between the village and the city induces intergenerational transfer of knowledge between old and young generations mainly through oral narratives. This study concludes that it is important to consider population mobility of the young generation to predict knowledge loss.
\end{abstract}

Keywords: Knowledge exchange, plant knowledge richness, population mobility, upland village

\section{INTRODUCTION}

Plants knowledge has notably had positive impact on the economic and health care development, conservation, and sustainable development program ( Yuan et al. 2016; Baydoun et al. 2017; de la Parra and Quave 2017; Shrestha and Medley 2017; Pandey and Tripathi 2017). A plant knowledge approach to local culinary and healing practices has become essential for providing food and drug research (Quave and Pieroni 2015). In biodiversity, the knowledge on the utilization and types of germplasm is a prerequisite for the maintenance of food crops (Brouwer et al. 2016) and becomes a buffer of losing genetic diversity due to genetic pollution (Carvalho et al. 2012). In Indonesia, the recent development of plant use is reflected in the raising license application for distribution of traditional medicine. According to Drug and Food Monitoring Agency (Badan Pengawasan Obat dan Makanan- BPOM 2017), in the period of 2015 to 2017 , there was an increase in the applications for the traditional medicine distribution licenses; $34.46 \%$ from 2015 to 2016 , and $52.63 \%$ from 2016 to 2017. Accordingly, the permits issued by BPOM rose from $29.58 \%$ in 2016 to $56.90 \%$ in 2017 . At present, traditional medicines are easily found in the form of sachets at convenience stores at an affordable price.
However, some studies show that regional development and environmental changes often lead to the loss of local plants use (Wiryono et al. 2017; Aswani et al. 2018; Hopping et al. 2018; Ludwinsky and Hanazaki 2018; Suryana et al. 2018; Wiryono et al. 2019). In Colombia, unsustainable land use, overharvesting, and climate change are the direct causes of declining availability of medicinal plants (Rodríguez et al. 2018). Some studies show that caution is needed to declare the loss of ethnobotanical knowledge (Carvalho et al. 2012; Vandebroek and Balick 2012). Transformation, segmentation, and heterogeneity of ethnobotanical knowledge are also influenced by demographic, geographic, and communication factors (Mathez-Stiefel and Vandebroek 2012; Pirker et al. 2012; Hopkins et al. 2015; Caneva et al. 2017; Weckmüller et al. 2019). Levi-Strauss (Levi-Strauss 1966) argues that traditional knowledge is rooted in day-to-day curiosity to solve problems and fulfill the needs. Thus, it differentiates knowledge as a concept of know and a practice of knowhow. Continuous desirable results substantiate the need of mastering and transferring knowledge to the next generation (Tam 2015; Sharif et al. 2016).

This study reveals the richness of plant knowledge consisting of plant names, uses, and cultivation sites, related to population mobilization in Sindangsari Village, West Java Province, Indonesia. 


\section{MATERIALS AND METHODS}

\section{Study area}

This research was undertaken in Sindangsari, Sumedang, West Java Province, Indonesia (Figure 1). Sindangsari is an upland village situated at around $1,287 \mathrm{~m}$ above sea level in the hillside of Manglayang Mountain (Figure 2). The climate of Sindangsari belongs to type A (MoA 2015). The average annual temperatures range from $25^{\circ} \mathrm{C}$ to $30^{\circ} \mathrm{C}$, and the humidity varies between $79 \%$ to $82 \%$. It has an average annual rainfall in between 1,294$2,827 \mathrm{~mm}$ with a sequential pattern of monsoonal. The highest rainfall usually occurs in January. In June, July, Augustus, and September, rainfall is usually low. The number of dry months with intensity $<100 \mathrm{~mm} /$ month is 3 5 months, and intensity $>200 \mathrm{~mm} /$ month is 6-7 months. As there is no fully linked irrigation channel infrastructure, the village agricultural activities depend on the season.

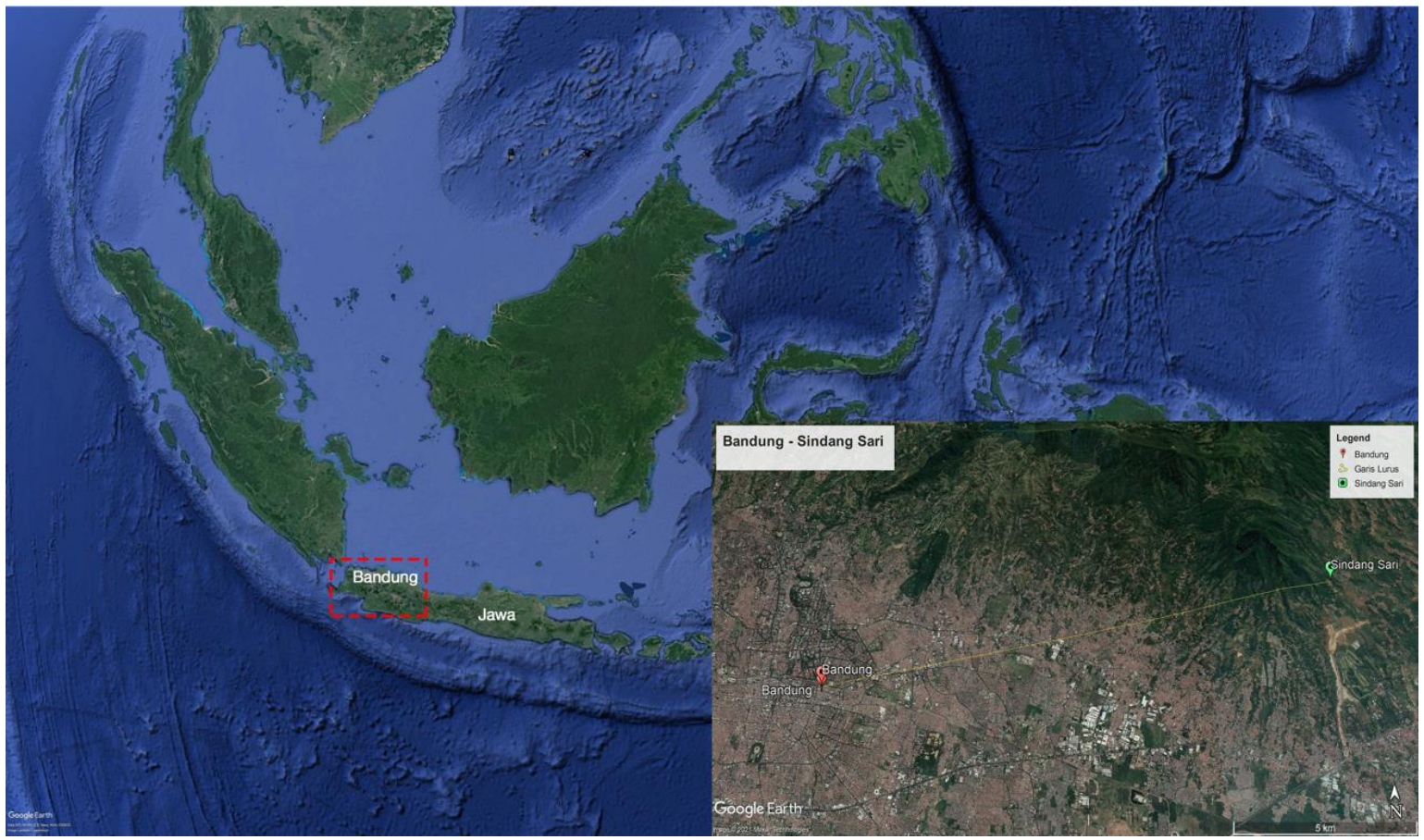

Figure 1. Study area, Sindangsari Village, Sukasari Sub-District, Sumedang District, West Java, Indonesia

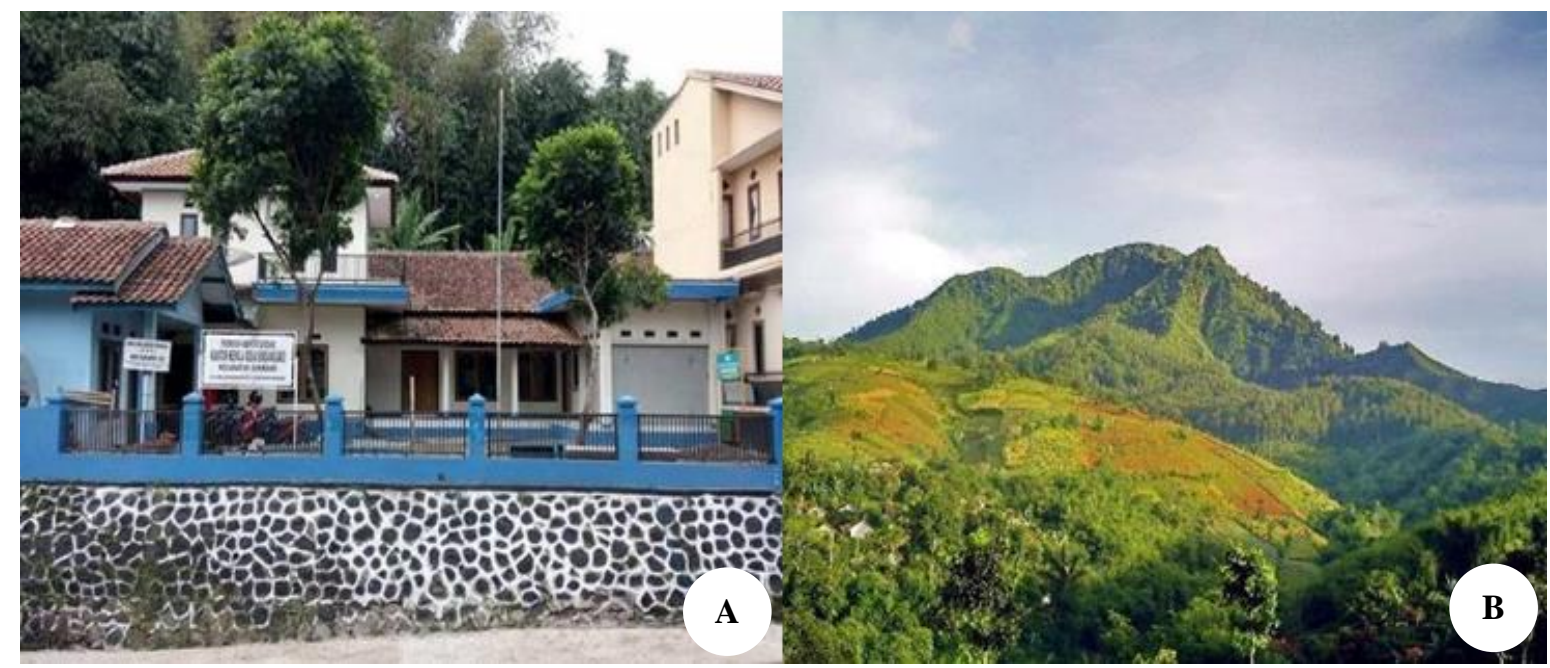

Figure 2. The village office (A) is located in the Manglayang mountain valley (B) of Sumedang District, West Java, Indonesia 
The Sindangsari population is dominated by the Sundanese who have been practicing agricultural way of life for generations. Their village land consists of 69 ha sawah (irrigated ricefields) and 509 ha other rain-fed rice fields, gardens, and homegardens. During the dry season, there is usually no enough water for agriculture (Kabupaten Sumedang 2018). The village flat lands cater freshwater fishes and chickens whilst the hilly ones are for goats, sheeps, and cows.

\section{Procedures}

The methodology used in this study was mixed-method with ethnobotanical approach to provide complementary insights into the overall topic of interest, which is focused on the interaction of plants and village people (Newing et al. 2010). Lynch et al. (1974) statistical formula was used to determine the number of random respondents. The calculation is as follow:

$$
\begin{aligned}
& n=\frac{N \times Z^{2} \times P(1-P)}{N \times d^{2}+Z^{2} \times P(1-P)} \\
& \mathrm{n}: \text { sample number (respondents) }=91 \\
& \mathrm{~N}: \text { total population of households }=1891 \\
& \mathrm{Z}: \text { normal variable value }=1.96 \\
& \mathrm{P}: \text { possible maximum proportion }=0.50 \\
& \mathrm{~d}: \text { error }=0.10 \\
& =\frac{1891 \times 1.96^{2} \times 0.50(1-0.50)}{1891 \times 0.1^{2}+1.96^{2} \times P(1-0.50)}=\frac{1816.12}{19.87}=91.4
\end{aligned}
$$

The total number of respondents was 91. The demographic data recorded age, sex, occupation, and place of residency. There is no record of formal education as it has not significantly affected traditional knowledge (Surtikanti et al. 2019); and plants knowledge listed ricefield, home garden, and garden plants name and use. The survey was followed by 'walking in the field', observation 'on the practice of plants use', and in-depth interviews (Tongco 2007). The informants were purposely selected based on their competency, that is local experts, including the village leader and his staff, informal leaders, men, women, young and old (Martin 2004; Torres-Avilez, de Medeiros, and Albuquerque 2016; Voeks 2007; Albuquerque et al. 2017). The research was undertaken from July to August 2017 and March 2018. The interview was carried out in both Bahasa Indonesia, and local language, Sundanese. Prior informed consent was always obtained.

\section{Data analysis}

Qualitative data were analyzed by several steps namely cross-checking, summarising, and synthesizing from different sources to build up a narrative account (Newing et al. 2010). The cross-checking was undertaken to check the correct data collected by direct observation and answers from some informants, including some document reports and statistical data. The appropriate data were then summarized and synthesized. Furthermore, a narrative, which is descriptive analysis and evaluative, was made.
While, the quantitative data were analyzed using statistics, the frequency was calculated based on a respondent's answer to the total respondents, then the descriptive analysis and evaluation were narrated. Some books, including Backer and Bakhuizen v.d. Brink (1963, 1965, 1968), Heyne (1987), Partoharjono and Grubben (1996), Siemonsa and Grubben (1996), and Widjaja (2019) were used to identify the plant species in the study area.

The quantitative data collected by structured interview with respondents were analyzed by simple statistical calculation as follows (Newing et al. 2010):

$$
\begin{aligned}
& P=\frac{\mathrm{f}}{\mathrm{n}} x 100 \% \\
& \text { Where, } \\
& \mathrm{P} \quad \text { : percentage of the total answer of respondents } \\
& \mathrm{f} \quad: \text { number of respondent answers } \\
& \mathrm{n} \quad \text { : total respondent }
\end{aligned}
$$

The results of statistical analysis were interpretationed and narrated with descriptive and evaluated analyses.

\section{RESULTS AND DISCUSSION}

The demographic data recorded in Table 1 show that the highest number of respondents is in the age between 41 to 50 years. They are within the highest demand category for economic, social, and cultural choruses of households and families. The occupation composition is expected to result in knowledgeable respondents; the composition of women to men, 61: 30, means that plants for medicinal uses may represent more than other uses. Many literature mentions the richness of medicinal knowledge belongs to women (Alqethami et al. 2017) who mostly work on homegarden; the place of residency distributed to nine neighborhood associations may represent extensive dissemination of knowledge throughout the village.

\section{The landrace in Sindangsari}

The interviews with respondents revealed that 204 landraces were found in the agroecosystem types, namely wet-rice fields, gardens, and homegarden. We use the word landrace which is applied by scholars, including Iskandar and Ellen (Iskandar and Ellen 1999) to distinguish local categories of plants, based on knowledge of Sindangsari people, Sumedang, with Western botanical sense. The landrace is different from the botanical scientific name in that it is based on categories for subdivision of ancestral plant species and varieties in the conventional Western taxonomic sense. Total 204 landraces documented in Sindangsari consists of 181 species, representing 161 genera, and 70 families (Figure 3). Figure 3 shows the ratio between the number of plants species, citations, and secondary citations show the narrow diversity use per plant. 
Table 1. Demographic data of respondents of Sindangsari Village, West Java, Indonesia

\begin{tabular}{|c|c|c|}
\hline Demographic data & $\mathrm{n}=91$ & $\%$ \\
\hline \multicolumn{3}{|l|}{ Age } \\
\hline $21-30$ & 10 & 10.99 \\
\hline $31-40$ & 19 & 20.89 \\
\hline $41-50$ & 28 & 30.77 \\
\hline $51-60$ & 17 & 18.68 \\
\hline $61-70$ & 11 & 12.09 \\
\hline $71-80$ & 3 & 3.30 \\
\hline $81-90$ & 3 & 3.30 \\
\hline \multicolumn{3}{|l|}{ Sex } \\
\hline Men & 30 & 32.97 \\
\hline Women & 61 & 67.03 \\
\hline \multicolumn{3}{|l|}{ Occupation } \\
\hline Worker $^{\mathrm{a}}$ & 12 & 13.19 \\
\hline Housewife ${ }^{b}$ & 34 & 37.36 \\
\hline Farmer $^{\mathrm{c}}$ & 18 & 19.78 \\
\hline Breeders $^{\mathrm{d}}$ & 4 & 4.40 \\
\hline Entrepreneur ${ }^{\mathrm{e}}$ & 18 & 5.50 \\
\hline No job ${ }^{f}$ & 5 & 19.78 \\
\hline \multicolumn{3}{|l|}{ Place of Residency } \\
\hline Salam (RW1) & 5 & 5.49 \\
\hline Salam (RW2) & 6 & 6.59 \\
\hline Babakan Kawung (RW3) & 19 & 20.88 \\
\hline Babakan Kawung (RW4) & 18 & 19.78 \\
\hline Babakan Kawung (RW5) & 1 & 1.09 \\
\hline Sindanglaya (RW6) & 5 & 5.49 \\
\hline Sindanglaya (RW7) & 11 & 12.09 \\
\hline Cibacang (RW8) & 25 & 27.47 \\
\hline Cibacang (RW9) & 1 & 1.10 \\
\hline Total & 91 & 100.00 \\
\hline
\end{tabular}

Note: The occupation classification follows the Indonesian Central Bureau of Statistics (Badan Pusat Statistik Indonesia), which is then modified following natives definition. However, there are no clear cut in-between categories, but they are the respondents' first occupation. (i) A worker is a respondent who mainly has routine and full-time work outside agricultural sector, such as civil servants and factory laborers. (ii) A housewife is a respondent who mostly spends their time on domestic chor ${ }^{\text {es. (iii) }} \mathrm{A}$ farmer is a respondent who mainly works in agricultural sector. Amongst them are the farmer with their land, a worker who works on someone else's land, a farmer who seeds for trading, and a farmer who has small number of livestock such as chicken and sheep. (iv) A breeder is a respondent who keeps livestock, and planting grasses, for trading. The livestock generally includes sheep, goat, and cow. (v) An entrepreneur is a respondent who owns a business. Some respondents open a small village shop. Included in this category is respondent who makes a house wall from woven bamboo. ${ }^{\mathrm{f}} \mathrm{A}$ no job is a respondent who is not able to do a job. They are not able due to being physically unable or being 'sepuh' (lit. old age); thus, they are not allowed to work by their relatives.

\section{The traditional knowledge of species in Sindangsari}

On the survey of the plants use, the various plants can be categorized into twelve: food, spices, medicine, construction, ornament, cosmetic, commercial plants, fodder, industry, food color, erosion control, and social function, as shown in Table 2, while, more detail of the plant species and commonly utilized by the village people of Sindangsari can be seen in Figure 4.
Figure 4 shows that the plants usage overlap in-between categories, that is one species may have more than one category of use. For example, one plant may be used for curing illnesses, for spices and ornament, and so on (Figure 5 ). It means the definition of category itself may sometimes overlap. For example, medicine is defined as plants to cure illnesses, but sometimes it also includes plants for preventing illnesses (but also in spices category) and casting out a negative supernatural power (an ornament).

The category of plants for food and medicine shows significantly a high number of species and secondary use. The most cited plant use category is food, followed by medicine, commercial, ornament, spices, and construction. The sum citations of other uses of plants, such as food color, cosmetics, fodder, industrial, erosion control, and social functions, have fallen to no more than 10 citations. The data represent that plants link to people immediate compare to secondary needs are likely cited higher. Interestingly, although, by the number, the category of social function are cited low, the informants emphasize its importance.

\section{Knowledge on cultivated site and knowledge distribution}

On the survey of plant cultivation sites, it was found that based on respondent perception, 108 landraces were present in homegardens, 55 in gardens, and 41 in sawahs, as shown in Table 3. The result may link to the higher number of women respondents than men. Further, the definition of sawah and garden are interchangeable depending on the season. As the time of the survey is in the dry season, sawah is drying up and the respondent defines some as garden. This dried-up sawah is planted with seasonal garden species (Figure 6).

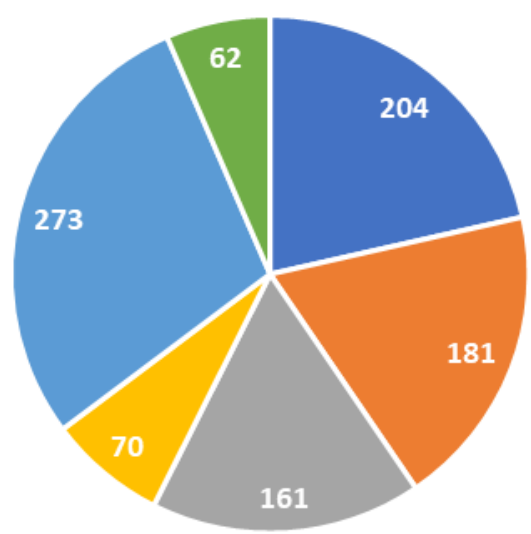

- Number of landraces - Number of genera

- Number of citations

- Number of species - Numbe of families

- Number of secondary citations

Figure 3. Summary of the number of useful plants classification and citation 


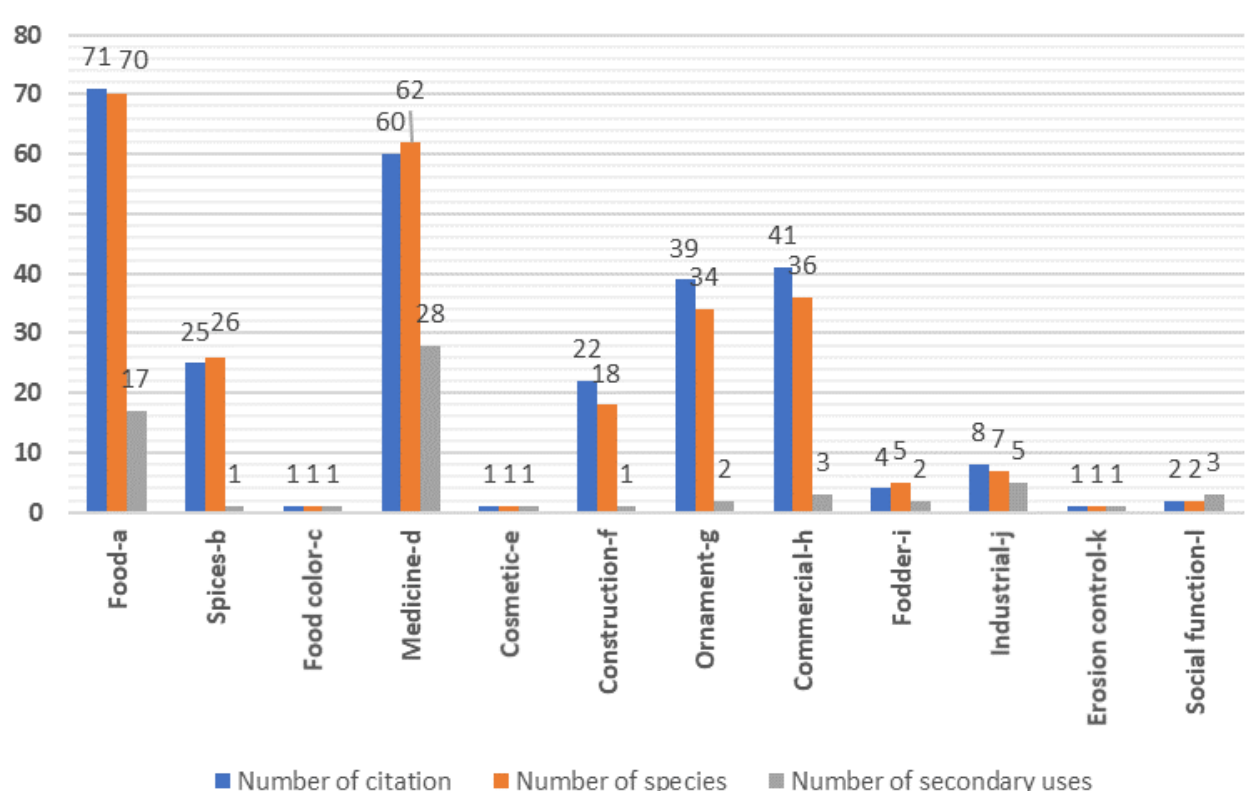

Figure 4. The main functions of plants and number citations are based on respondents. Note: The category definition of plants use as respondents explain them: Food: plants that are eaten on their own or together with other parts of the plants: fresh fruits, vegetables, lalab (raw vegetables to be eated with chili sauce or paste), lotek (salad of slightly boiled), leaf jelly (cincau), sambal (chili sauce or paste), combro (grated cassava and oncom, fermented peanut residue), chips (kiripik). Spices: herbs. Food color: color additives for food. Medicine: high blood pressure, constipation, diabetes, flatulence, cracked skin, diarrhea, kidney disease, sore iching, uric acid, skin itchy, stomach problems, maintain health, ulcers abscess, gout, fever, heartburn, rheumatic, cough, muscle pain, chills, stomach ache, myalgia, gastric problem, diuretic problem, back pain, sprue, sprain, external wound, toothache, postnatal care, hair care, casting out negative supernatural power. Cosmetic: plants for face powder. Construction: plants for building materials. Ornament: plants for adding aesthetics values to house, including casting out a negative supernatural power. Commercial: plants that can be sold, such as wood, seeds/seedling, and firewood. Fodder: plants for animal food, such as beehives. Industry: processed products. Erosion control: plant to prevent avalanche. Social functions: plants to be shared with neighbors, give a shade for people, or function as windbreak for the village.

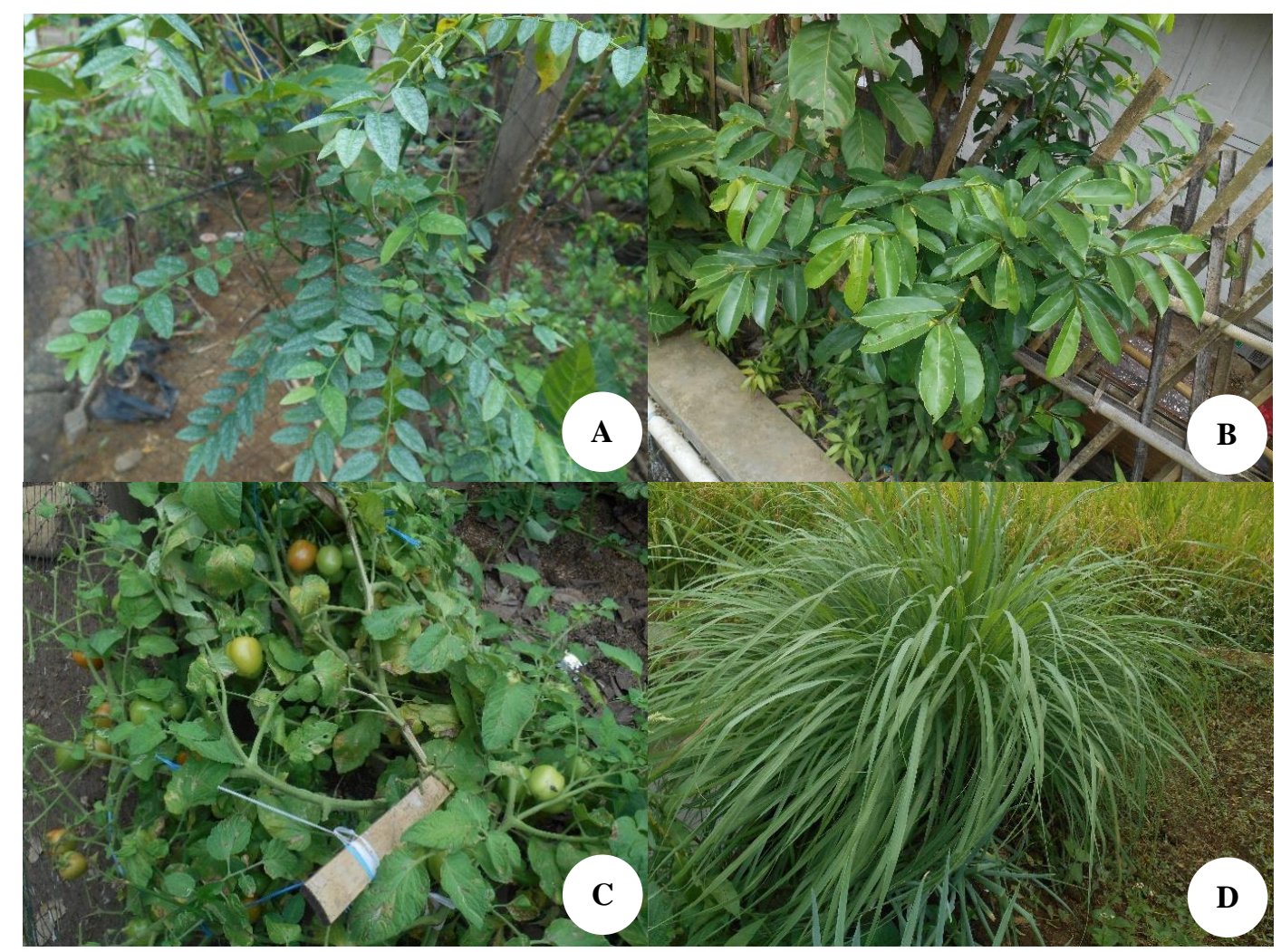

Figure 5. A. Katuk (Sauropus androgynus)-leaves are used as vegetable and medicinal feverish; B. Manalika (Anona muricata) fruit is used as fresh fruit and medicinal stomach; C. Tomat (Solanum lycopersicum)-fruit is used as spices and medicinal sprue (left); D. Sereh (Cymbopogon citratus) stem is used as spices and as medicinal a high blood pressure 
Table 2. Plant species and various utilizations based on interview with respondents in the Sindangsari, Sumedang, Indonesia

\begin{tabular}{|c|c|c|c|c|}
\hline \multirow{2}{*}{$\begin{array}{l}\text { Vernacular } \\
\text { name/landraces }\end{array}$} & \multirow{2}{*}{ Scientific name } & \multirow{2}{*}{ Family } & \multicolumn{2}{|r|}{ Utilization } \\
\hline & & & Plant part & Used method/function \\
\hline Akasia & Acacia decurrens Willd & Fabaceae & Seedling & The seedlings are sold; function as commercial \\
\hline Alkor & Sp. 3 & & Trunk & The wood is used for construction materials; functions as construction \\
\hline Alpuket/Alpukat & Persea americana Mill & Lauraceae & Fruit & $\begin{array}{l}\text { The fruit is used as fresh fruit, to treat high blood pressure, and sold; function as food, } \\
\text { medicine, commercial }\end{array}$ \\
\hline Anggrek kalajengking & Arachys flos-aeris (L) Archb.f & Orchidaceae & Flower & The flowers are used for ornament; function as ornament \\
\hline Anggur & Vitis vinifera $\mathrm{L}$ & Vitaceae & Fruit & The fruit is used as fresh fruit; functions as food \\
\hline Antanan & Centella asiatica $(\mathrm{L})$ Urban & Apiaceae & Leaf & The leaves are used to treat itchy skin; function as medicine \\
\hline Arbei & Morus alba $\mathrm{L}$ & Moraceae & Fruit & $\begin{array}{l}\text { The fruit is used as fresh fruit, to treat high blood pressure and constipation; function as food, } \\
\text { medicine }\end{array}$ \\
\hline Aren/Kawung & Arenga pinnata (Wurmb) Merr & Arecaceae & $\begin{array}{l}\text { Inflorescences, } \\
\text { fruit }\end{array}$ & $\begin{array}{l}\text { The inflorescences are sap for making sugar, fruits are made for making sweetmeat (kolang- } \\
\text { kaling); function as an industry }\end{array}$ \\
\hline Asem & Tamarindus indica $\mathrm{L}$ & Fabaceae & Fruit & The fruit is used for spices; function as food \\
\hline Awi betung & $\begin{array}{l}\text { Dendrocalamus asper (Schult.f) } \\
\text { Backer }\end{array}$ & Poaceae & Clums & The culms are used for construction material; function as construction, industry \\
\hline Awi cangker & Bambusa sp. & Poaceae & Clums & The culms are used as ornament; function as ornament \\
\hline $\begin{array}{l}\text { Awi gombong, Awi } \\
\text { surat }\end{array}$ & $\begin{array}{l}\text { Gigantochloa verticillata (Willd) } \\
\text { Munro }\end{array}$ & Poaceae & Clums & The culms are used for sale, construction materials, tools; function as construction, industry \\
\hline Awi hideung & Gigantochloa atroviolacea Widjaja & Poaceae & Clums & $\begin{array}{l}\text { The culms are used for construction materials and Sundanese musical instrument material } \\
\text { (calung); function as construction, industry }\end{array}$ \\
\hline Awi tali & Gigantochloa apus (Schult.f) Kurz & Poaceae & Clums & $\begin{array}{l}\text { The culms are used for sale, construction material, woven bamboo, and kite; function as } \\
\text { construction, industry }\end{array}$ \\
\hline Awi temen & Gigantochloa atter (Hassk) Kurz & Poaceae & Clums & The culms are used for construction and for sale; function as construction and industry \\
\hline Bako/Tembakau & Nicotiana tabacum $\mathrm{L}$ & Solanceae & Leaf & The leaves and processed leaf products are sold; function as industry \\
\hline Bakung & Crinum asiaticum $\mathrm{L}$ & Liliaceae & Flower & The flowers are used as ornament; function as ornament \\
\hline Baluntas & Pluchea indica $\mathrm{L}$ & Lauraceae & Leaf & The leaves are used to treat stomach problems; function as medicine \\
\hline Bambu totol & Bambusa maculata Widjaja & Poaceae & Tree & The tree is used as ornament; function as ornament \\
\hline Batrawali & Tinospora crispa $\mathrm{L}$ & Menispermaceae & Stem & The stem is used to maintain health; function as medicine \\
\hline $\begin{array}{l}\text { Bawang beureum/ } \\
\text { Bawang merah }\end{array}$ & Allium fistulosum $\mathrm{L}$ & Amaryllidaceae & Bulb & The bulb is used as spices, and sold; function as spices, commercial \\
\hline Bawang daun & Allium fistulosum $\mathrm{L}$ & Amaryllidaceae & Leaf & The leaves are used as spices, sold, and given to neighbors; function as species, commercial, social \\
\hline Bawang gajah & Allium fistulosum $\mathrm{L}$ & Amaryllidaceae & Bulb & The bulb is used as spices; function as spices \\
\hline Bayem hejo & Amaranthus hybridus $\mathrm{L}$ & Amaranthaceae & Leaf & The leaves and stems are cooked and consumed; function as food \\
\hline $\begin{array}{l}\text { Bayem beureum/ } \\
\text { Bawang merah }\end{array}$ & Amaranthus tricolor $\mathrm{L}$ & Amaranthaceae & Stem & The stem and leaves are used as vegetable, and to treat gout; function as food, medicine \\
\hline Belimbing & Averrhoa carambola $\mathrm{L}$ & Amar & Fruit & The fruit is eat \\
\hline Binahong & Anredera cordifolia (Ten) Stenis & Basellaceae & Leaf & $\begin{array}{l}\text { The leaves are used to treat high blood pressure, skin itchy, ulcers, immediately eaten; function } \\
\text { as medicine }\end{array}$ \\
\hline Bonsai beringin & Ficus benjamina $\mathrm{L}$ & Moraceae & Tree & The tree is used as ornament; function as ornament \\
\hline
\end{tabular}


Borneo

Brokol

Buah/Mangga

Buah naga

Bugenvil

Buncis

Buntiris

Cabe bendot

Cabe kriting

Cabe/Cabe merah

Calincing

Caludih

Camcau/Cincau

Campoleh

Cangkudu/ Mengkudu

Cau bogo

Cau nangka

Cecenet/Ceplukan

Cempaka putih

Cengek

Cengkeh

Cikur/Kencur

Dangdeur

Daun adam hawa

Daun edi

Daun insulin

Daun sembung

Delima

Engkol/Kol

Eurih

Gabon, Jabon

Gedang/Pepaya

Gedang rant

Ginseng

Hanjuang
Sp. 4

Brassica olercea var. "italica"

Mangifera indica $\mathrm{L}$

Brassicaceae

Anacardiaceae

Hylocereus lemairei (Hook.) Briton Cactaceae

\section{\& Rose}

Bougenvillea spectabilis Willd Nyctaginaceae

Phaseolus vulgaris L Papilionaceae

Kalanchoe piñata (Lamk) Pers Crassulaceae

Capsicum annum L. var "grossum" Solanaceae

Capsicum annum $\mathrm{L} \quad$ Solanaceae

Capsicum annum $\mathrm{L} \quad$ Solanaceae

Oxalis acetosella $\mathrm{L}$

Oxalidaceae

Gynura divaricata (L.) DC

Cyclea barbata Miers

Madhuca cuneta (B1,) Macbr.

Asteraceae

Menispermaceae

Morinda citrifolia $\mathrm{L}$

Sapotaceae

Rubiaceae

Musa x varadisiaca L var."sapientum" Musaceae

Musa $\times$ paradisiaca

Musaceae

Musa $x$ paradisiaca $\mathrm{L}$

Physalis angulate $\mathrm{L}$

Musaceae

Magnolia champaca (L.) Figlar Magnoliaceae

Solanaceae

Capsicum frutescens $\mathrm{L}$

Myrtaceae

Zingiberaceae

Bombaceae

Commelinaceae

Malvaceae

Bombax ceiba L

Rhoeo spathacea (Sw.) Stearn

Abelmoschus manihot $\mathrm{L}$

Smallanthus sonchifolius Poepp \& Endl Asteraceae

Blumea balsamifera $\mathrm{L}$

Punica granatum $\mathrm{L}$

Acanthaceae

Punicaceae

Malvaceae

Brassicaceae

Imperata cylindrica C.E. Hubb

Anthocephalus cadamba Miq

Carica papaya $\mathrm{L}$

Graminae

Rubiaceae

Caricaceae

Carica papaya $\mathrm{L}$

Panax sp

Cordyline fruticosa (L.) A.Chev Asparagacea
Trunk

Leaf

Fruit and tree The fruit is used as fresh fruit, the trees is used as shade from the sunshine and to blocking the The leaves are used as vegetable and sold; function as food, commercial

Fruit The fruit is used as fresh fruit and sold; function as food, commercial

Flower

Fruit

Leaf

Fruit

Fruit

Fruit

Leaf

Leaf

Leaf

Fruit

Fruit

Fruit

Fruit

Flower

Fruit

Fruit

Rhizome

Leaf

Leaf

Leaf

Leaf

Fruit

Fruit

Root and stem

Trunk

Fruit and lea

Fruit

Plant

strong wind; function as food, social

The flowers are used as ornament; function as ornament

The fruits are used as vegetable and sold; function as food, commercia

The leaves are used to treat fever and heartburn; function as medicine

The fruits are used as spices; function as spices

The fruits are used as spices; function as spices

The fruits are used as spices and sold; function as spices, commercial

The leaves are used to treat fever, diarrhea; function as medicine

The leaves are used to treat fever, stomach ache; function as medicine

The leaves are used for making a leaf jelly (cincau) and eaten; function as food

The fruit is used as fresh fruit; function as food

The fruit is used to treat high blood pressure; function as medicine

The fruit is used as fresh fruit, and sold; function as food, commercial

The fruit is used as fresh fruit, and sold; function as food, commercial

The fruit is used as fresh fruit, and sold; function as food, commercial

The fruit is used to treat back pain; function as medicine

The flower is used for ornament; function ornament

The fruit is eaten directly, chilly sauce, processed to lotek (salad of slightly boiled), treat external wound, and sold; function as food, medicine, commercial

The fruit is used to treat stomach aches; function as medicine

The rhizome is used as spices; function as spices

The leaves are used to treat stomachache; function as medicine

The plant is used as ornament; function as ornament

The leaves are used to treat sprue; function as medicine

The leaves are used to treat diabetes; function as medicine

The leaves is used to treat flatulence; function as medicine

The fruit is used as fresh fruit; function as food

The fruit is used as fresh fruit; function as food

The leaves for fresh vegetable, and made for lotek (salad of slightly boiled), sold; function as food, commercial

Roots and stems are used to treat high blood pressure; function as medicine

The wood is used for construction materials; function as construction

The fruit, young fruit is used as salad, young leaves as vegetables, to treat cracked skin; function as food, medicine

The fruit is used to treat ulcer; function as medicine

The roots are used to maintain health; function as medicine

The plant is used as ornament, and to withhold negative supernatural power; function as

ornament, medicine 


\begin{tabular}{|c|c|c|c|c|}
\hline Haur hejo & Bambusa vulgaris var striata & Poaceae & Tree & The tree is used as ornament; function as ornament \\
\hline Haur hitam & Gigantochloa atroviolacea Widjaja & Poaceae & Tree & The tree is used as ornament; function as ornament \\
\hline Haur koneng & $\begin{array}{l}\text { Bambusa vulgaris var "vulgaris" } \\
\text { Schrad. ex J.C. Wendl }\end{array}$ & Poaceae & Tree & The tree is used as ornament; function as ornament \\
\hline Hiris & Cajanus cajan (Linn.) Mills & Leguminosae & Bean & The beans are used as vegetable and to make salad; function as food \\
\hline Honje & Etlingera elatior (Jack) R.M Smith & Zingiberaceae & Fruit, flower & The fruit and flower are used as spices, and to treat high blood pressure; function as spices, medicine \\
\hline Hui/Ubi & Ipomoea batatas (L.) Lam & Convolvulaceae & Tuber & The tuber is used as food, sold; function as food, commercial \\
\hline Indri & Sp. 5 & & Trunk & The wood is used as construction material, sold; function as construction, commercial \\
\hline Jagong & Zea mays $\mathrm{L}$ & Poaceae & Bean & The roasted and boiled corn are used as food, processed, and sold; function as food, commercial \\
\hline Jahe & Zingiber officinale Roscoe & Zingiberaceae & Rhizome & The rhizome is used as spices, and to treat toothache; function as spices, medicine \\
\hline Jambe/Pinang & Areca catechu $\mathrm{L}$ & Arecaceae & Fruit & The fruit is used for chewing; function as food \\
\hline Jambu batu/Jambu biji & Psidium guajava $\mathrm{L}$ & Myrtaceae & Fruit & The fruit is used as fresh fruit; function as food \\
\hline Jambu air & Syzigium aquaeum (Burm.f.) Alston & Myrtaceae & Fruit & The fruit is used as fresh fruit; function as food \\
\hline Jaringao & Acorus calamus $\mathrm{L}$ & Accoraceae & Leaf & The leaves are used to treat myalgia (nyeri otot); function as medicine \\
\hline Jati/Jati bodas/Jabon & Gmelia arborea Roxb & Verbenaceae & Trunk & The wood is used as construction material, sold; function as construction, commercial \\
\hline Jawer kotok & Coleus scutellaroides (L.) Benth & Lamiaceae & Leaf & $\begin{array}{l}\text { The leaves are used to treat gastric problem, and recovering women after giving birth; function } \\
\text { as medicine }\end{array}$ \\
\hline Jawer ayam & Celosia argentia L var. "cristata" & Amaranthaceae & Plant & The plant is used as ornament; function as ornament \\
\hline Jayanti & Sesbania sesban (L) Merr & Fabaceae & Leaf & The leaves are used to treat high blood pressure, diuretic problems; function as medicine \\
\hline Jengjen/Albasiah & Paraserianthes falcataria (L.) Nielsen & A Fabaceae & Trunk & The wood is used for construction material; function as construction \\
\hline Jengkol & $\begin{array}{l}\text { Archidendron pauciflorum (Benth) } \\
\text { I.C Nielsen }\end{array}$ & Fabaceae & Fruit & The fruits are used as vegetable; function as food \\
\hline Jeruk & Citrus sp. & Rutaceae & Fruit & The fruit is used as fresh fruit, to treat fever; function as food, medicine \\
\hline Jeruk purut & Citrus hystrix DC & Rutaceae & Fruit & The fruits are used as various spicy side dishes (sambal); function as spices \\
\hline Jeruk lemon & Citrus limon $\mathrm{L}$ & Rutaceae & Fruit & The fruit is used as spices; function as spices \\
\hline Jeruk garut & Citrus sp. & Rutaceae & Fruit & The fruit is used as fresh fruit; function as food \\
\hline Jeruk bali & Citrus maxima (Burm.) Merr. & Rutaceae & Fruit & The fruit is used as fresh fruit; function as food \\
\hline Jeruk nipis & Citrus aurantifolia (Christm) & Rutaceae & Fruit & The fruit is used for spices; function as spices \\
\hline Jeruk paris & Sp.1 & & Fruit & The fruit is used as fresh fruit; function as food \\
\hline Jukut ibun & Drynaria hirsute Bartl & Caryophyllaceae & Leaf & The grasses are used to treat ulcer abscess, constipation; function as medicine \\
\hline $\begin{array}{l}\text { Jukut } \\
\text { benggala/Kaso/Bede }\end{array}$ & Pennisetum pupureum Schumach & Poaceae & Leaf & The grasses are used for fodder; function as fodder \\
\hline $\begin{array}{l}\text { Jukut pager/Rumput } \\
\text { pagar }\end{array}$ & Duranta erecta $\mathrm{L}$ & Verbenaceae & Plant & The plant is used for ornament; function as ornament \\
\hline Jukut pelak & Sp. 11 & & Leaf & The grasses are used for fodder; function as fodder \\
\hline Kacang panjang & Vigna ungiculata $(\mathrm{L})$ Walp & Fabaceae & Bean & The bean is used as vegetable, sold; function as food, commercial \\
\hline $\begin{array}{l}\text { Kacang beureum/ } \\
\text { Kacang merah }\end{array}$ & $\begin{array}{l}\text { Vigna angularis (Willd) Ohwi \& } \\
\text { H.Ohashi }\end{array}$ & Fabaceae & Bean & The bean is used as vegetable, sold; function as food, commercial \\
\hline Kacapiring & Gardenia augusta (L.) Merr & Rubiaceae & Plant & The plant for ornament, function as ornament \\
\hline Kaktus & Mammillaria $\mathrm{sp}$ & Cactaceae & Plant & The plant for ornament, function as ornament \\
\hline Kalendra & Acasia abida (Del.) & Fabaceae & $\begin{array}{l}\text { Stem, flower, } \\
\text { tree }\end{array}$ & $\begin{array}{l}\text { The stems and trees are used as firewood, leaves as fodder, and flowers are used as source food } \\
\text { of honey bees; function as commercial, fodder }\end{array}$ \\
\hline Kaliajet & Sp. 6 & & Plant & The plant for ornament, function as ornament \\
\hline Kaliki beureum & Jatropha gossypifolia L. & Euphorbiaceae & Leaf & The leaves are used to release constipation, function as medicine \\
\hline Kalitis/Litus & Eucalyptus sp. & Myrtaceae & Trunk & The wood is used as construction, function as construction \\
\hline
\end{tabular}




\begin{tabular}{|c|c|c|c|c|}
\hline Kamboja & Plumeria acuminata W.T. Aiton & Apocynaceae & Plant & The plant is used for ornament, function as ornament \\
\hline Kamper & Dryolanops aromatic Gaertn.F & Dipterocarpaceae & Trunk & The wood is used for construction, sold; function as construction, commercial \\
\hline Kangkung darat & Ipomoea reptans $\mathrm{L}$ & Convolvulaceae & Leaf & The leaves and stems are cooked as vegetable; function for food \\
\hline Kapol & Amomum cordomomum $(\mathrm{L})$ Maton & Zingiberaceae & Fruit & The fruit is used to treat high blood pleasure; function as medicine \\
\hline Kapulaga & Elettaria cardamomum (L) Malton & Zingiberaceae & Rhizome & The rhizome is used as spices, to treat stomach problems; function as spices, medicine \\
\hline Karet & $\begin{array}{l}\text { Hevea brasiliensis (Willd ex A. } \\
\text { Juss) M.A }\end{array}$ & Euphorbiaceae & Sap & Sap is tapped and sold; function as commercial \\
\hline Katuk/Katepos & Sauropus andoroginus (L.) Merr & Phyllanthaceae & Leaf & The leaves are used as vegetable, cooked, to treat fever; function as food, medicine \\
\hline Kaweni & Mangifera odorata Griff & Anacardiaceae & Fruit & The fruit is used as fresh fruit; function as food \\
\hline Kedelai & Glycine $\max (\mathrm{L}$.$) Merr$ & Fabaceae & Bean & The bean is used as vegetable; function as food \\
\hline Kelapa & Cocos nucifera $\mathrm{L}$ & Arecaceae & Fruit & The fruit is used as fresh drink; function as food \\
\hline Keladi & Collocasia esculenta (L.) Schott & Araceae & Plant & The plant is used as ornament; function as ornament \\
\hline Kemuning & Muraya paniculata $(\mathrm{L})$. & Rutaceae & Seedling & The seedlings are usually sold; function as commercial \\
\hline Kentang & Solanum tuberosum $\mathrm{L}$ & Solanaceae & Tuber & The tuber is usually sold; function as commercial \\
\hline Kiciat & Ficus septica Burm.f. & Moraceae & Leaf & The leaves are used to treat gastric pain or gastric ulcer; function as medicine \\
\hline Kiciwis & Brassica oleracea $\mathrm{L}$ & Brassicaceae & Leaf & The leaves are used as salad of slightly boiled (sayur lotek); function as food \\
\hline Kijambe & Cycas revolute Tunb & Cycadaceae & Trunk & The wood is used as construction material; function as construction \\
\hline Ki urat & Plantago major $\mathrm{L}$ & Plantaginaceae & Leaf & The leaves are used to treat sprain, high blood pressure, back pain; function as medicine \\
\hline Koneng/Kunyit & Curcuma longa $\mathrm{L}$ & Zingiberaceae & Rhizome & The rhizome is used as spices, sold; function as spices, commercial \\
\hline Kopi & Coffea arabica $\mathrm{L}$ & Rubiaceae & Fruit, seeds & $\begin{array}{l}\text { The fruits are used to treat fever, mature seeds are sold, and seedling are sold; function as } \\
\text { medicine, commercial }\end{array}$ \\
\hline Kumis kucing & Orthosiphon aristatus (Blume) Miq & Lamiaceae & Leaf & $\begin{array}{l}\text { The leaves are used to treat fever, rheumatics, high blood pressure, cough, constipation; } \\
\text { function as medicine }\end{array}$ \\
\hline Kuping gajah & Anthurium sp & Araceae & Plant & The plant is used as ornament; function as ornament \\
\hline Laja & Alpinia galanga $(\mathrm{L})$ Willd & Zingiberaceae & Rhizome & The rhizome is used as spices, to treat muscle pain; function spices, medicine \\
\hline Lampuyang & Zingiber zerumbet (L.) Smith & Zingiberaceae & Rhizome & The rhizome is used to treat high blood pressure; function as medicine \\
\hline Lejet/Waluh siem & Sechium edule (Jacq) Sw & Cucurbitaceae & Fruit & $\begin{array}{l}\text { The fruit is used as cooked vegetable, made lotek (salad of slightly boiled), to treat high blood } \\
\text { pressure; function as food, medicine }\end{array}$ \\
\hline Lengkeng & Dinocarpus longan Lour & Sapindaceae & Fruit & The fruit is used as fresh fruit; function as food \\
\hline Leunca & Piper nigrum $\mathrm{L}$ & Piperaceae & Fruit & the fruit is used as fresh vegetable and cooked; function as food \\
\hline Lidah buaya & Aloe vera $\mathrm{L}$ & Asphodelaceae & Leaf & The leaves is used to treat fever, heartburn, external wound, hair care; function as medicine \\
\hline Lidah mertua & Sansieviera $\mathrm{sp}$ & Asparagaceae & Plant & The plant is used as ornament; function as ornament \\
\hline Lili paris & $\begin{array}{l}\text { Chlorophytum comosum (Thunb) } \\
\text { Jaques }\end{array}$ & Agavaceae & Plant & The plant is used as ornament; function as ornament \\
\hline Mahkota dewa & $\begin{array}{l}\text { Phalaeria macrocarpa (Scheff) } \\
\text { Boerl }\end{array}$ & Thymelaeaceae & Fruit & The fruit is used to treat diabetes; function as medicine \\
\hline Mahkota duri & Euphorbia millii Des Moul & Euphorbiaceae & Plant & The plant is used as ornament; function as ornament \\
\hline Mahoni & Swietenia mahagoni (L.) Jacq & Meliaceae & Trunk, seeds & $\begin{array}{l}\text { The wood is used as construction material, seeds are used to treat high blood pressure; function } \\
\text { as construction, medicine }\end{array}$ \\
\hline Manalika/Sirsak & Annona muricata $\mathrm{L}$ & Annonaceae & Fruit & The fruit is used as fresh fruit, to treat diarrhea; function as food, medicine \\
\hline Markisa & Passiflora edulis Sims & Passifloraceae & Fruit & The fruit is used as fresh fruit, to treat stomach ache; function as food, medicine \\
\hline Mawar & Rosa hybrida Hort & Rosaceae & Plant & The plant is used as ornament; function as ornament \\
\hline Muncang/Kemiri & Aleurites moluccana (L.) Willd & Euphorbiaceae & Fruit & The fruits are sold; function as commercial \\
\hline Nanas & Ananas comosus (L) Merr & Bromelioideae & Fruit & The fruit is used as fresh fruit; function as food \\
\hline
\end{tabular}




\begin{tabular}{|c|c|c|c|c|}
\hline Nangka & Artocarpus heterophyllus Lam & Moraceae & Fruit, trunk & $\begin{array}{l}\text { The fruit is used as fresh fruit, cooked, sold, its wood is used as construction material; function } \\
\text { as food, construction }\end{array}$ \\
\hline Pacing & Costus speciosus (J. Koeinig) Sm & Costaceae & Rhizome & The rhizome is used to treat kidney disease; function as medicine \\
\hline Paku ekor kuda & Equisetum debille Roxb ex. Vaucher & Equisetaceae & Plant & The plant is used as ornament; function as ornament \\
\hline Palem & Crytostachys renda Blume & Arecaceae & Plant & The plant is used as ornament; function as ornament \\
\hline Pandan wangi & Pandanus amaryllifolius Roxb & Pandanaceae & Leaf & The leaves are used as spices; function as spices \\
\hline Panglay & Zingiber cassumunar Roxb & Zingiberaceae & Rhizome, plant & $\begin{array}{l}\text { The rhizome is used as spices, the plant to protect from negative supernatural power: function } \\
\text { as spices, medicine }\end{array}$ \\
\hline Pare/Padi & Oryza sativa $\mathrm{L}$ & Poaceae & Fruit & The fruits are used as staple food; function as food \\
\hline Pecah beling & Strobilantes crispus $\mathrm{L}$ & Acanthaceae & Fruit & The leaves are used as to treat fever, the feeling of chills; function as medicine \\
\hline Pecay & Brasica oleracea $\mathrm{L}$ & Brasicaceae & Leaf & The leaves are used as vegetable, sold; function as food, commercial \\
\hline Peuteuy/Petai/Pete & Parkia speciosa Hassk & Fabaceae & Fruit & The fruit is used as vegetable; function as food \\
\hline $\begin{array}{l}\text { Peuteuy selong/ } \\
\text { Selong/Lamtoro }\end{array}$ & Leucaena leucocephala Hassk & Fabaceae & Fruit & The mature fruits are cooked as vegetable; function as food \\
\hline Pilisium/Kiara payung & Filicium decipiens (Wight \& Arn) & Sapindaceae & Trunk & The wood is used as construction material, sold; function as construction, commercial \\
\hline Pinus & Pinus merkusii Jungh. \& de Priese & Pinaceae & Trunk & The wood is used as construction material; function as construction \\
\hline Pisuk & Sp. 7 & & Trunk & The wood is used for construction, sold; function as construction, commercial \\
\hline Pohpohan & Pilea melastomoides (Poir) B1 & Urticaceae & Leaf & The leaves are used as vegetable, to maintain health; function as food, medicine \\
\hline Pucuk merah & Syzigium myrtifolium Walp & Myrtaceae & Plant & The plant is used as ornament, sold; function as ornament, commercial \\
\hline Pupur Jawa & Sp. 8 & & Leaf & The leaves are used as powder cosmetic; function as cosmetic \\
\hline Puring & Codiaeum variegatum $\mathrm{L}$ & Euphorbiaceae & Plant & The plant is used as ornament; function as ornament \\
\hline Puspa & Schima wallichii (DC) Korth & Theaceae & Trunk & The wood is used as construction material; function as construction \\
\hline Rambutan & Nephelium lappaceum $\mathrm{L}$ & Sapindaceae & Fruit & The fruit is used as fresh fruit; function as food \\
\hline Rosela & Hibiscus sabdariffa $\mathrm{L}$ & Malvaceae & Flower & The flowers are used to maintain health; function as medicine \\
\hline Roay & Lablab purpureus (L.) Sweet & Fabaceae & Bean & The beans are used as vegetable; function as food \\
\hline Randa midang & Cosmos caudatus Kunth & Asteraceae & Leaf & The leaves are used to treat gastric problems; function as medicine \\
\hline Rumput carulang & Eulisine indica (Linn) Gaertn & Poaceae & Leaf & The grasses are used as fodder; function as fodder \\
\hline Saga & Abrus precatorius $\mathrm{L}$ & Fabaceae & Leaf & The leaves are used to treat cough; function as medicine \\
\hline Salak & Salacca zapota (L.) P.Royen & Sapotaceae & Fruit & The fruit is used as fresh fruit; function as food \\
\hline Selada bokor & Nasturtium officinale W.T Aiton & Brassicaceae & Leaf & The leaves are used as vegetables; function as food \\
\hline Saledri & Apium graveolens $\mathrm{L}$ & Apiaceae & Leaf & $\begin{array}{l}\text { The leaves are used as spices, vegetable, to treat high blood pressure; function as spices, } \\
\text { medicine }\end{array}$ \\
\hline Salam & $\begin{array}{l}\text { Syzygium polyanthum (Wight) } \\
\text { Walp }\end{array}$ & Myrtaceae & Leaf & The leaves are used as spices; function as spices \\
\hline Salowedia & Sp.9 & & Plant & The plant is used as ornament, sold; function as ornament, commercial \\
\hline Sambiloto & $\begin{array}{l}\text { Adrographis paniculata (Burm.f.) } \\
\text { Wall ex Nees }\end{array}$ & Acanthaceae & Leaf & The leaves are used to treat fever; function as medicine \\
\hline Sambung nyawa & Gynura procumbens (Lour) Merr & Asteraceae & Leaf & The leaves are used to treat diabetes; function as medicine \\
\hline Sampeu/Singkong & Manihot esculenta Crantz & Euphorbiaceae & Tuber & $\begin{array}{l}\text { The tuber is used as food, cooked leaves is used as vegetable, made of cassava chips (kiripik), } \\
\text { mixed with fermented cake made from peanut sediment (combro), sold; function as food, commercial }\end{array}$ \\
\hline Sancang & Premna microphylla Turcz & Lamiaceae & Plant & The plant is used as ornament; function as ornament \\
\hline Sawo & Manilkara zapota $(\mathrm{L})$ & Sapotaceae & Fruit & The fruit is used as fresh fruit; function as food \\
\hline Sebet/Bunga tasbih & Canna hybrid Hort ex Back & Cannaceae & Plant & The plant is used as ornament; function as ornament \\
\hline Sedap Malam & Polianthes tuberosa $\mathrm{L}$ & Amaryllidaceae & Plant & The plant is used as ornament; function as ornament \\
\hline Sereh/Serai & Cymbopogon citratus (DC) Stapf & Poaceae & Stem and leaf & The stem is used as spices, leave is used to treat high blood pressure; function as spices, medicine \\
\hline
\end{tabular}




\begin{tabular}{|c|c|c|c|c|}
\hline Seureuh/Sirih & Piper betle $\mathrm{L}$ & Piperaceae & Leaf & The leave is used to treat sore itching, chewing (nyeupah); function as food, medicine \\
\hline Sikas & Cycas circinalis $\mathrm{L}$ & Cycadaceae & Plant & The plant is used as ornament, sold; function as ornament, commercial \\
\hline Sintrong & $\begin{array}{l}\text { Crassocephalum crepidioides } \\
\text { (Benth) }\end{array}$ & Asteraceae & Leaf & The leaf is used as vegetable; function as food \\
\hline Sobsi/Kayu Afrika & Maesopsis eminii Engl & Rhamnaceae & Trunk & The wood is used as construction; function as construction \\
\hline Sosin & Brassica rapa $\mathrm{L}$ & Brassicaceae & Leaf & The leaf is used as vegetable, cooked, sold; function as food, commercial \\
\hline Sri rejeki & Aglaonema sp & Araceae & Plant & The plant is used as ornament; function as ornament \\
\hline Stroberi & Fragaria $x$ ananassa Duch & Rosaceae & Fruit & The fruit is used as fresh fruit; function as food \\
\hline Suji & Pleomele angustifolia (Roxb) N.E. Br & Agavaceae & Leaf & The leaves are used as food coloring; function as food color \\
\hline Sukun & $\begin{array}{l}\text { Artocarpus communis (Parkison) } \\
\text { Fosberg }\end{array}$ & Moraceae & Fruit & The fruit is used as fresh fruit; function as food \\
\hline Surawung & Ocimum basilicum $\mathrm{L}$ & Lamiaceae & Leaf & $\begin{array}{l}\text { The leaf is used as spices, vegetable, sauce made by crushing spices in a mortar (sambal } \\
\text { nyibek); function as food, spices }\end{array}$ \\
\hline Surian/Suren & Toona sureni (Blume) Merr & Meliaceae & Trunk & The wood is used as construction material; function as construction \\
\hline Suuk/Kacang tanah & Arachis hypogaea $\mathrm{L}$ & Fabaceae & Fruit & The fruit is used as food, made lotek (salad of slightly boiled), sold; function as food, commercial \\
\hline Taleus lahun indung & Collocasia esculenta (L.) Schott & Araceae & Tuber & The tuber is used as food, to treat high blood pressure; function as food, medicine \\
\hline Taleus padang & Colocasia esculenta $(\mathrm{L})$ Schott & Araceae & Tuber & The tuber is used as food, to treat high blood pressure; function as food, medicine \\
\hline Takokak & Solanum torvum $\mathrm{Sw}$ & Solanaceae & Leaf & The leaves are used to treat uric acid; function as medicine \\
\hline Tangkil/Malinjo & Gnetum gnemon $\mathrm{L}$ & Gnetaceae & Fruit & The fruit is used as vegetable; function as food \\
\hline Temu kunci & Boesenbergia rotunda (L.) Mansf & Zingiberaceae & Rhizome & The rhizome is used as spices; function as spices \\
\hline Tapak dara & Catharanthus roseus (L.) G.Don & Apocynaceae & Plant & The plant is used as ornament; function as ornament \\
\hline Tepemegah tanah & Sp10 & & Tree & The trees are used as soil erosion control; function erosion control \\
\hline Terong & Solanum melongena $\mathrm{L}$ & Solanaceae & Tree & the fruit is used as fresh vegetable and cooked; function as food \\
\hline Tisuk & $\begin{array}{l}\text { Hibiscus macrophyllus Roxb. } \\
\text { ex.Hornem }\end{array}$ & Malvaceae & Trunk, tree & $\begin{array}{l}\text { The wood is used as construction material, tree is used as ornament; function as construction, } \\
\text { ornament }\end{array}$ \\
\hline Tiwu/Tebu & Sacharum officinarum $\mathrm{L}$ & Poaceae & Stem & The thick stem is made sugar; function as food \\
\hline Tomat & Solanum lycopersicum $\mathrm{L}$ & Solanaceae & Fruit & The fruit is used as spices, fresh fruit, to treat sprue, sold; function as food, spices, medicine \\
\hline Wijaya kusumah & Epiphyllum anguliger (Lem.) G.Don & Cactaceae & Plant & The plant is used as ornament; function as ornament \\
\hline
\end{tabular}




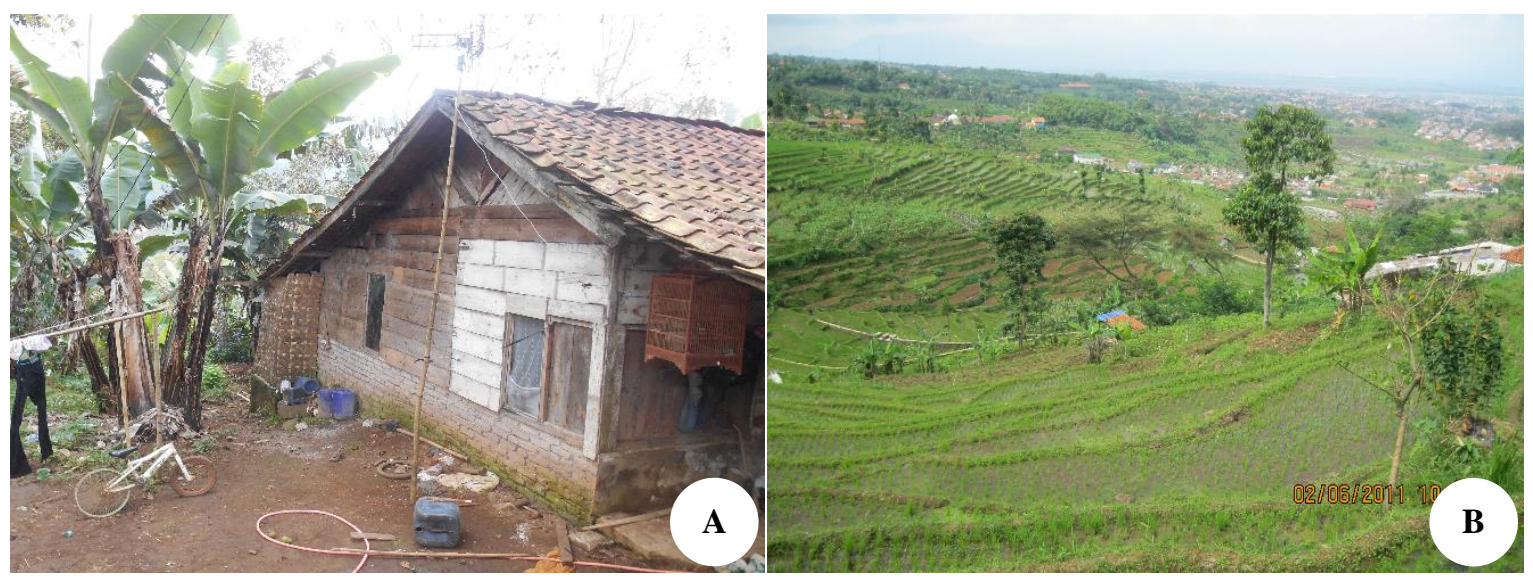

Figure 6. The homegarden (A) and the wet-rice rice field is usually planted by various non-rice crops during the dry season (B)

Table 3 shows that it is generally accepted that the diversity of crops in wet-rice fields or gardens is lower than that of homegarden (Iskandar and Iskandar 2011). The village homegardens of West Java not only function as settlement but also in a variety of other roles. In a typical village in West Java, the houses are almost completely concealed by trees which has an important role in ecological functions, including hydrologic and erosion control, gene bank, and microclimatic effect, and socioeconomic functions, such as subsistence and commercial production of fruits, vegetable, spices, and so on (Soemarwoto and Soemarwoto 1984).

In terms of the village knowledge, based on the survey of distribution of knowledge, it revealed that two to 10 people cited 80 species. This is the highest number of species cited by respondents. It means that the wealthiest use of plants species knowledge belongs to two to 10 people, and 41 to 50 people only known one species. The deep knowledge of plants uses confine to restricted people within population (Table 4).

The depth interview, observation, and 'walk in the fields' revealed that the younger generation memorized the names and uses of plants but doubtful to point out plants when in the field. For example, one informant confidently spelled the name and use of panglay (Zingiber cassumunar) but failed to identify the panglay when they grew in groups with similar plants. Panglay is one of the most ingredients in quite lots of rituals.

\section{Richness of plant knowledge}

Some factors affect the richness of plants knowledge. In the research of plants knowledge of the upland people of Sindangsari, the combination of the mobility of young generation takes a decisive role, added by the modernization of health and food system as an interfering factor.

The government's policy to establish Jatinangor as the Higher Education Region (Kawasan Pendidikan Tinggi), at about five-kilometer, opens opportunities for the Sindangsari population to work outside their village. Interviews with parents, young people, and the wives of the
Sindangsari residents show that they agree and encourage their relatives to find a job in Jatinangor. However, most Sindangsari people work in low-paid jobs; therefore, they keep attached to the village, which provides the silih life, taking care of each other. As the silih is enforced through village ceremonies and rituals that construct and enforce kinship, the mobile villagers being enforced to be participated (Janowski and Kerlogue 2007). However, the rituals involve plants elaboration and transformation from one state to another, physically and spiritually, such as the rice grains (pare) to rice (nasi) from the sacred to mundane. To fulfill the participation, the mobile villagers arrange for someone else to accomplished the task for them. As a result, they have lost their practical ability. The skill of practicing for the young mobile villagers becomes doubtful and less convincing. Moreover, the young have learned to use ready-made herbal sachets.

Table 3. Cultivated site and number of species based on respondents of Sindangsari people

\begin{tabular}{lcc}
\hline Agroecosystem types & $\begin{array}{c}\text { Number of } \\
\text { landraces }\end{array}$ & $\begin{array}{c}\text { Percent to } \\
\text { total (\%) }\end{array}$ \\
\hline Homegarden & 108 & 52.94 \\
Garden & 55 & 26.96 \\
Sawah* & 41 & 20.09 \\
Total & 204 & 100.00 \\
\hline
\end{tabular}

Note: *) During the dry season is predominantly planted by nonpaddy

Table 4. The plant species are recognized by respondent $(n=91)$

\begin{tabular}{lcc}
\hline Respondent number & $\begin{array}{c}\text { Species number } \\
\text { recognized }\end{array}$ & Percentage of total \\
\hline $51-55$ & 2 & 1.10 \\
$41-50$ & 1 & 0.55 \\
$31-40$ & 2 & 1.10 \\
$21-30$ & 6 & 3.31 \\
$11-20$ & 12 & 6.62 \\
$2-10$ & 89 & 49.17 \\
1 & 70 & 0.55 \\
Total 91 respondents & 181 species & 100.00 \\
\hline
\end{tabular}


In this study, it can be concluded that 204 landraces were recognized by the village people of Sindangsari, Sumedang. Based on scientific-botanical knowledge, it consists of 181 species, representing 161 genera, and 70 families. This research presents case of plants knowledge decline due to development, particularly among the young generation. In the form of knowledge, the Sindangsari people practice less of their traditional plants knowledge.

\section{ACKNOWLEDGEMENTS}

We would like to thank the Ministry of Research and Technology for funding this research. The profound gratitude goes to all informants and respondents in Sindangsari Village, Sumedang, who patiently and generously shared their knowledge on ethnobotany with us. We also like to thank the head of village of Sindangsari who provided permission for undertaking the field research in the Sindangsari. Also, appreciation for all research assistants, Hanna, Ama, dan Yudistira, for their hard work at a time of gathering data.

\section{REFERENCES}

Albuquerque UP, Cruz da Cunha LVF, Lucena RFP, Alves RRN. 2017. Methods and Techniques in Ethnobiology and Ethnoecology. Humana Press, New York

Alqethami A, Hawkins JA, Teixidor-Toneu I. 2017. Medicinal plants used by women in Mecca: urban, muslim, and gendered knowledge. J Ethnobiol Ethnomed 13: 62. DOI: 10.1186/s13002-017-0193-4.

Aswani S, Lemahieu A, Sauer WH. 2018. Global trends of local ecological knowledge and future implications. PLoS ONE 13 (4) DOI: 10.1371/journal.pone.0195440.

Backer CA, Bakhuizen v.d. Brink RC. 1963, 1965, 1968. Flora of Java Vol. 1-3. WoltersNoordhoff NV, Groningen.

Baydoun S, Kanj D, Raafat K, Aboul Ela M, Chalak L, Arnold Apostolides N. 2017. Ethnobotanical and economic importance of wild plant species of Jabal Moussa Bioreserve, Lebanon. J Ecosyst Ecogr 7 (3). DOI: 10.4172/2157-7625.1000245.

Brouwer B, Winkler L, Atterberry K, Jones S, Miles C. 2016. Exploring the role of local heirloom germplasm in expanding Western Washington dry bean production. Agroecol Sustain Food Syst 40 (4) 319-332. DOI: 10.1080/21683565.2015.1138013.

Caneva G, Traversetti L, Sujarwo W, Zuccarello V. 2017. Sharing ethnobotanical knowledge in traditional villages: evidence of food and nutraceutical 'core groups' in Bali, Indonesia. Econ Bot 71 (4):. 303-313. DOI: 10.1007/s12231-017-9395-x.

Carvalho M, Bebeli P, Bettencourt E, Costa G, Dias S. 2012. Cereal landraces genetic resources in worldwide genebanks. A review. Agron Sustain Dev 33 (1): 177-203. DOI: 10.1007/s13593-012-00900 .

Heyne K. 1987. Indonesian Useful Plants (Indonesian). Forestry Research and Development Agency, Jakarta.

Hopkins AL, Stepp JR, McCarty C, Gordon JS. 2015. Herbal remedy knowledge acquisition and transmission among the Yucatec Maya in Tabi, Mexico: A cross-sectional study. J Ethnobiol Ethnomed. DOI: 10.1186/s13002-015-0022-6.

Hopping KA, Chignell SM, Lambin EF. 2018. The demise of caterpillar fungus in the Himalayan Region due to climate change and overharvesting. Proc Nat Acad Sci USA 115 (45): 11489-11494. DOI: $10.1073 /$ pnas.1811591115.

Iskandar J, Ellen R. 1999. In situ conservation of rice landraces among the Baduy of West Java. J Ethnobiol 19 (1): 97.125.

Iskandar J, Iskandar BS. 2011. Agroecosystem of the Sundanese People (Indonesian). Kiblat Utama, Bandung.

Janowski M, Kerlogue F (eds.). 2007. Kinship and Food in South East Asia. NIAS -Nordic Institute of Asian Studies, Copenhagen.
BPS. 2018. Kabupaten Sumedang dalam Angka (Sumedang District in Figures). Badan Pusat Statistik, Sumedang. [Indonesian]

la Parra J de, Quave CL. 2017. Ethnophytotechnology: Harnessing the Power of Ethnobotany with Biotechnology. Trends Biotechnol 35 (9): 802-806. DOI: 10.1016/j.tibtech.2017.07.003.

Levi-Strauss C. 1966. The Savage Mind. Weidenfeld and Nicolson, London.

Ludwinsky RH, Hanazaki N. 2018. Ethnobotany in a coastal environmental protected area: shifts in plant use in two communities in southern Brazil. J Ethnobiol Ethnomed 14: 65. DOI: 10.1186/s13002-018-0265-0.

Lynch SJF, Hoelnsteiner RM, Cover CL. 1974. Data Gathering by Social Survey. Philippines Social Science Council, Quezon City.

Martin GJ. 2004. Ethnobotany: A Methods Manual. Ethnobotany: A Methods Manual. Routledge, London. DOI: 10.4324/9781849775854.

Mathez-Stiefel SL, Vandebroek I. 2012. Distribution and transmission of medicinal plant knowledge in the Andean Highlands: A Case Study from Peru and Bolivia. Evid-Based Compl Altern Med 2012: 959285. DOI: $10.1155 / 2012 / 959285$.

Newing H, Eagle CM, Puri RK, Watson CW. 2010. Conducting Research in Conservation: Social Science Methods and Practice. Routledge, London. DOI: 10.4324/9780203846452.

Pandey AK, Tripathi YC. 2017. Ethnobotany and its relevance in contemporary research. J Med Plants Stud 5 (3): 123-129.

Partoharjono S, Grubben GJH. 1996. Plant Resources of South-East Asia No. 10. Cereals. Prosea, Bogor.

Pirker H, Haselmair R, Kuhn E, Schunko C, Vogl CR. 2012. Transformation of traditional knowledge of medicinal plants: the case of Tyroleans (Austria) who migrated to Australia, Brazil and Peru. J Ethnobiol Ethnomed 8: 44. DOI: 10.1186/1746-4269-8-44.

Quave CL, Pieroni A. 2015. A reservoir of ethnobotanical knowledge informs resilient food security and health strategies in the Balkans. Nature Plants 1 (2): 14021. DOI: 10.1038/nplants.2014.21.

MoA [Ministry of Agriculture] 2015. Atlas Peta Pengembangan Kawasan Padi, Kabupaten Sumedang, Provinsi Jawa Barat. Kementerian Pertanian, Republik Indonesia, Jakarta. [Indonesian]

Rodríguez MA, Angueyra A, Cleef AM, Van Andel T. 2018. Ethnobotany of the Sierra Nevada Del Cocuy-Güicán: Climate Change and Conservation Strategies in the Colombian Andes. J Ethnobiol Ethnomed 14: 1. DOI: 10.1186/s13002-018-0227-6.

Sharif MSM, Mohd Zahari MS, Md Nor N, Muhammad R. 2016. The importance of knowledge transmission and its relation towards the Malay Traditional food practice continuity. Procedia Soc Behav Sci. 85: 227-235. DOI: 10.1016/j.sbspro.2016.05.215.

Shrestha S, Medley KE. 2017. Integrating ecological and ethnobotanical knowledge to promote collaborative conservation planning in the Nepal Himalaya. Mountain Res Dev 37 (1): 97-107. DOI: 10.1659/mrd-journal-d-15-00081.1.

Siemonsa JS, Grubben GJH. 1996. Plant Resources of South-East Asia No 8 Vegetables. Pudoc Scientific Publisher, Wageningen.

Soemarwoto O, Soemarwoto I. 1984. The Javanese rural ecosystem. In: Rambo AT, Sajise PE (eds.). An Introduction to Human Ecology Research on Agricultural System in Southeast Asia, University of the Philippines Los Banõs, Laguna.

Surtikanti HK, Syulasmi A, Fatimah T. 2019. Traditional knowledge of local wisdom of Aga Tenganan Pegringsingan Bali about environmental conservation and sanitation. J Phys Conf Ser 1157: 022117. DOI: 10.1088/1742-6596/1157/2/022117.

Suryana, Iskandar J, Parikesit, Partasasmita R. 2018. Ethnobotany of tree ferns in Pasir Menyan Hamlet, Sukamandi Village, Subang, West Java, Indonesia. Biodiversitas 19 (6): 2044-2051. DOI: 10.13057/biodiv/d190609.

Tam KP. 2015. Understanding intergenerational cultural transmission through the role of perceived norms. J Cross-Cult Psychol 46 (10): 1260-1266. DOI: 10.1177/0022022115600074.

Tongco MDC. 2007. Purposive sampling as a tool for informant selection. Ethnobot Res Appl 5: 147-158. DOI: 10.17348/era.5.0.147-158.

Torres-Avilez W, Muniz de Medeiros P, Albuquerque UP. 2016. Effect of gender on the knowledge of medicinal plants: systematic review and meta-analysis. Evid-Based Compl Altern Med 2016: 6592363. DOI: $10.1155 / 2016 / 6592363$.

Vandebroek I, Balick MJ. 2012. Globalization and loss of plant knowledge: challenging the paradigm. PLoS ONE 7 (5): e37643. DOI: 10.1371 journal.pone.0037643.

Voeks RA. 2007. Are Women Reservoirs of Traditional Plant Knowledge? Gender, Ethnobotany and Globalization in Northeast 
Brazil. Singapore J Tropical Geography 28 (1): 7-20. DOI 10.1111/j.1467-9493.2006.00273.x.

Weckmüller H, Barriocanal C, Maneja R, Boada M. 2019. Factors affecting traditional medicinal plant knowledge of the Waorani, Ecuador. Sustainability (Switzerland) 11 (16): 4460. DOI: $10.3390 /$ su 11164460

Widjaja EA. 2019. The Spectacular Indonesian Bamboos. Polagrade, Jakarta.

Wiryono, Japriyanto, Erniwati. 2017. The diversity of locally utilized plants and local botanical knowledge in Central Bengkulu District, Bengkulu Province, Indonesia. Biodiversitas 18 (4): 1596-1601. DOI: 10.13057/biodiv/d180437.
Wiryono, Sriwahyuni, Winanda GA, Saprinurdin, Nurliana S. 2019. The diversity of useful plants and botanical knowledge of the Rejang Tribe in Kepahiang District, Bengkulu Province, Indonesia. Biodiversitas 20 (12): 3599-3607. DOI: 10.13057/biodiv/d201219.

Wiryono, Wanandi Y, Ilahi AK, Deselina, Senoaji G, Siswahyono. 2019. The local knowledge of the plant names and uses by Semende Tribe People in Kaur District, Bengkulu Province, Indonesia. Biodiversitas 22 (7): 2739-2754. DOI: 10.13057/biodiv/d200320.

Yuan H, Ma QQ, Ye L, Piao GC. 2016. The traditional medicine and modern medicine from natural products. Econ Bot 21 (5): 559-577. DOI: $10.3390 /$ molecules 21050559 . 